\title{
A Conceptual Framework in the Formation of Young Entrepreneurs in Indonesia
}

\author{
Rahmatiah $^{1}$ \\ Dondick Wicaksono Wiroto ${ }^{2}$ \\ Hapsawati Taan ${ }^{3}$
}

\begin{abstract}
This article is an initial step to reach a conceptual understanding on young entrepreneurs in sociological studies. Many studies pertaining to entrepreneurship have been found in various discipline of studies, however, nothing of note has been found particularly in connection to the concept of youth. The current reality in Indonesia precisely exhibits multiple entrepreneurship activities targeting young people as organizers and participants. The identity of entrepreneur is constructed by tracing and researching the variety of important concepts observed in various literature (written by economy, sociology, and entrepreneurship experts) concerning entrepreneur action. Entrepreneur identity has 4 dimensions: triggering event, innovation, action strategy of start-up arrangement (as stated in the business plan/model), and entrepreneurship implementation. Entrepreneur identity will be discussed by using multiple data obtained from YouTube in the form of speeches, lectures, and interviews of young entrepreneurs until an understanding is ultimately acquired regarding the identity of young entrepreneurs' base of action by analyzing their emphasis on what they do as entrepreneurs. The discussion develops further as the identity touches on a more complex social context: social welfare, hence, young entrepreneurs also have the identity of young entrepreneurs' social movement comprising of three phases: initiation, strategic, and control.
\end{abstract}

\section{Keywords:}

youth; entrepreneur; identity; start-up business; innovation.

\section{Introduction}

It is observed that numerous segments of entrepreneurial activities are being conducted by youngsters. SWA, an Indonesian business magazine, has been writing articles since 2003 not only on matters of business, but also concerning entrepreneurs and CEO's. It even has a special column regarding youngster which is divided into four different news categories: entrepreneur, start-up, self-employed, and professional. The magazine, in 2014, held an event named Young Business Movement 2014 in Jakarta which showcased three business categories of young entrepreneurs: entrepreneurship, start-up, and self-employed (Ratomo, 2014). Such various entrepreneurship activities targeting youngsters had subsequently become more widespread, among others were

\footnotetext{
1 Department of Sociology, Faculty of Social Science, Gorontalo State University. Email: rahmatiah.hadi@yahoo.com

2 Department of Sociology, Faculty of Social Science, Gorontalo State University. Email: dondickwwiroto@gmail.com

3 Department of Management, Faculty of Economy, Gorontalo State University.
} 
the Indonesia Youth to Business Forum in Surabaya held by the ITS campus in 2015, the National Seminar on Entrepreneurship: Java Overland Studentpreneur Competition 2014 held in Malang State University, and the National Seminar on Entrepreneurship and Independent Youth 2016: Effective Strategy to Success at a Young Age in the Era of the ASEAN Economic Community held at the Semarang National University. Young businesspeople, young entrepreneurs, young professionals, young motivators, and government figures were invited to present as key sources during those events.

These entrepreneurship events are merely following the popular trend prevalent in the wider community, as well as a result of their mutual concern in facing threats of unemployment and labor competition to youngsters who are currently pursuing their undergraduate degree. The concern over their employment status upon graduation and their apprehension as a generation expected to mature and become independent may surely lead these young people to experience difficulties in clearly understanding the roles and functions they should establish when deciding to become an entrepreneur. There is also the possibility that these youngsters have yet to clearly understand their presence in that situation as a symbol of the transitional process within the development of human life (Minza, 2014), as a generation symbol (a periodical context and condition of historical construct in the relation of the social-economic-political situations) (Sutopo, 2014), and also unavoidably as a part of the various other generations facing the rapid, immense, and subtle mass cultural penetration occurring through various legal specifications, which have instead symbolically caused transition and generation boundaries to become disorientating to the youngsters, particularly those living in cities and are diffused in mass society, because of their acquiring new status of membership within a subculture (Hodkinson, 2007: 4) and their increasingly shedding of their youth status from their cultural identity (Macionis, 2008: 71). Hence, the development of such entrepreneurship trend makes it more difficult to understand

Figure 1.

Advertisement Poster Samples for Events Encouraging Entrepreneurship for Young People
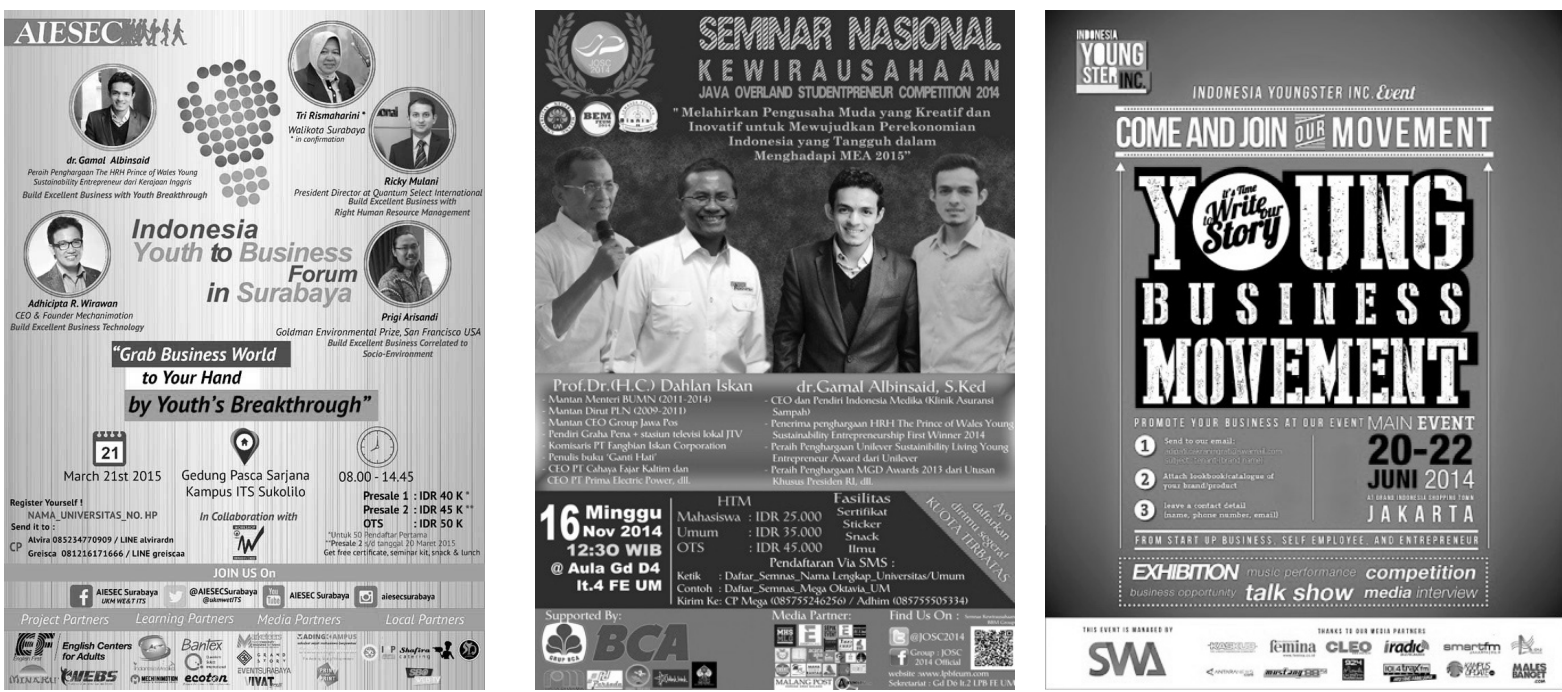

SM

Source: http://wartaagro.com/foto_berita/92indonesia-youth.jpg, http://media.halomalang.com/ media/2014/Events/10/31/B08kLB3CMAA5Jzf.jpg, http://asset-swa.cache.cdn.cdnet.co.id/wpcontent/uploads/2014/06/youngbusinessmovement_FREE.jpg 
the actual phenomenon of entrepreneurship among young people. They are also confronted with unpredictable conditions as a job seeker or a future entrepreneur. Becoming an employee seems to be the most rational choice, but they should also anticipate on becoming an entrepreneur as the risk of not securing employment increases and the opportunities in the informal sector become more available. Even so, the choice of becoming an entrepreneur, which may commonly be undertaken by youngsters having business experiences and family background in trade and business, remains to imbue a sense of unpredictability in the level of success that can be accomplished (Viinikainen et al. 2016).

In summary, the conditions faced by youngsters today compel them to adjust their intent and desire to very limited options that are restricted by an existing situation which agrees to market interests organized by dominant and collective actors (for more detailed elaboration on formulation of interests see Swedberg, 2005). However, this article does not discuss such particular condition, it instead focuses on how young people respond to this situation. This study attempts to initiate a conceptual framework regarding how youngsters respond to this situation and make the decision of taking on the identity as entrepreneurs. Giddens (1991) in Jenkins (2008) explains that identity formation is undertaken by putting emphasis on one's personal life, that is one's action and influence in forming their self-identity which provides the possibility of understanding themselves in terms of selfcontrol and planning their future self, namely as a young entrepreneur.

\section{Methods}

This study is a literature research utilizing qualitative methodology. We examined that the concepts of youth and entrepreneur identity have various interrelated definitions and that they are an initial part of the conceptual framework which will be developed through various qualitative studies (Neumann, 2013: 209-210). We consider various documents such as journal articles that discuss concept developments or research results, as well as interviews coverage, speeches, and lectures collected from YouTube, as required data which were subsequently examined to contribute in establishing an initial framework for developing a conceptual definition.

The respondents in the interviews coverage, who also have their speeches and lectures on YouTube, are Sandiaga Uno, Nadiem Makariem, Kevin Mintaraga, Budi Susilo Setiawan, and Haidhar Hibatullah Wurjanto. Sandiaga Uno name is taken because he is the most successful and most recognized young entrepreneur in Indonesia. Total time frame of analysis of the Sandiaga Uno speeches and lectures in Youtube is 2:50:23 hours. Nadiem Makariem is the founder of Gojek, a start-up unicorn in Indonesia. Total time frame of analysis of the Nadiem Makariem interview and lecture in Youtube is 1:34:11 hours. The name Kevin Mintaraga is found at YouTube when searching a successful young entrepreneur in building a start-up unicorn and selling it to other enterprise to get huge profit in order to start a new high innovation start-up. Total time frame of analysis of the Kevin Mintaraga interviews on Youtube is 48:30 minutes. Budi Susilo Setiawan and Haidhar Hibatullah Wurjanto are an alumnus of a university in Indonesia who have tried to build business organization since they were in college and now come as successful young entrepreneurs. There were many examples of young entrepreneurs compare to Budi and Haidhar in business interview coverage on YouTube, but only both of them gave the information which is adequate to our scope and focus of research. Total time frame of analysis of the Budi Susilo Setiawan interview on Youtube is 35:32 minutes and of the Haidhar Hibatullah Wurjanto interview is 12:34 minute. 
The data collected from YouTube is meant to enhance available data pertaining to empirical conditions of young entrepreneurs in Indonesia, in which it was acquired from a number of seasoned young entrepreneurs (Sandiaga Uno) and start-up entrepreneurs. These data are deemed necessary based on several considerations. Firstly, upon analysis of various literature, it is observed that researchers on entrepreneurship constantly develop and are very dynamic, which is similar to the personal character of entrepreneurs and the complexities of entrepreneurship, whereas the concept of youth is underdeveloped in the subculture category, thereby requiring direct explanations from individuals who are competent and experienced in this concept. Secondly, the definition of entrepreneur and matters pertaining to it differs throughout every social group as each depends on their own language (McKenzie, 2009) (for instance, the expectations and objectives of entrepreneurship, and the emphasis on specific values and attitudes to accomplish those expectations and objectives; and the measure of success and failure as an entrepreneur may also differ). Lastly, the various data obtained from assorted groups of people become a consideration in developing a conceptual framework of youngsters and entrepreneur identity into a dynamic conceptual framework on the identity of young entrepreneur - wherein literature on dynamic entrepreneurship conceptual framework remains very limited (Nassif, Ghobril, da \& Silva, 2010).

\section{Results and Discussion Conceptualizing Entrepreneur Identity}

William B. Gartner, in his 1988 article titled "Who is an entrepreneur is the wrong question" concluded that there is no significant agreement on who an entrepreneur is (Ruef, 2010: 7). Whereas, in order understand identity, it is essential to question who's who (for without doing so it will be difficult to understand what's what) (Jenkins, 2008). Hence, we need to initially observe the extent of the scope concerning entrepreneurship based on limitations set by existing literature.

Gartner (1988), emphasized the implication his research has for subsequent studies, wherein research on entrepreneurship should be oriented toward actions conducted by entrepreneurs in establishing and developing organizations. He further elaborated that the most important point of study concerns what skills entrepreneurs have and employ to accomplish these actions and where they can acquire these skills (Ruef, 2010: 7).

Howard E. Aldrich (2001) in Saade (2013) is of the same opinion that the study on entrepreneurship pertains to the formation of new organization, in which he also provided several weaknesses on the business growth approach, innovation approach, and opportunity identification approach. Entrepreneurship concerns nascent entrepreneur which is defined as individuals initiating significant activities with the intent of accomplishing a business start-up, wherein the activity conducted are gestation activity for business development.

Gestation activities for new ventures are one of the lifecycles of organization: gestation, creation, launching, and consolidation. Creation is initiated through gestation which comprises of concept, planning, and implementation (Aidin, 2015: 103). Gestation or preparation of new ventures consists of nine activities, among others: 1) developing business plan (written or unwritten); 2) developing a product or service; 3) planning marketing efforts; 4) speaking to potential customers; 5) collecting information on competitors; 6) creating financial projection; 7) approaching financial institutions or individuals for funding; 8) procuring facilities, necessities, properties or other tangible items; and 9) dealing with administrative matters on establishing a new business (Kautonen \& van Gelderen, 2015: 11). 
During the gestation period, entrepreneurs remain uncertain (Holm, Nee, \& Opper, 2011) in formulating opportunities and acquiring resources, and are, thereby, in need of a business plan able to serve as a complete strategy in establishing a new business organization (Samuelsson \& Davidsson, 2009; Bygrave \& Zacharakis, 2010: 56). The business plan comprises of several parts which should be fulfilled by the entrepreneur, namely: analysis on industry, consumers, and competitors; company and product description; marketing plan; operational plan; development plan; and identification of plausible risks; source of fund and its use; and financial report projection (Bygrave \& Zacharakis, 2010: 242-256).

To this point, it can be understood that entrepreneurs are people who undertake a set of strategic and organized actions through systematic business planning in order to develop a business organization, and they are individuals able to properly formulate their business opportunities and strategic actions for the sake of acquiring necessary resources. However, this definition has yet to provide an understanding that entrepreneurship is an identity. The entrepreneur's identity developed here remains very narrow and has not touched upon its sociological aspect.

In the distant past, Weber defined entrepreneur's identity as those possessing the spirit of capitalism formed through group loyalty of a Protestant religious sect in ascetic rationalism (a person's integrity of not committing moral violations is acknowledged through baptism (charisma and emphasis on charisma) and he obtains unlimited trust from the entire community wherein the consequently emerging ethic is that he would donate several sums of his money back to the Church for the sake of his sect) and those driven to induce changes in the conduct of entrepreneurs in businesses, from a lenient traditional form into a more modern one filled with logical reasoning of intense competition in order to generate money/profit (Ghosh, 2014: 25-26, 351-354). In short, entrepreneurs are those who have been afforded with God's blessings apparent through the profitability of their ventures and their life prosperity.

The definition specified in the work of Weber, when conceptualized as an identity by using the identity concept strategic scope of Jenkins (2008: 46), produces an understanding on entrepreneur identity, i.e. the result of constant dialectic between an individual and one's interaction space with its collective domain through an order consisting of a network of people with positions and routine practices bounded by "repertoires of intentionality" to define an individual as an entrepreneur with certain criteria in order to acquire and utilize resources and be identified from the organization of said resources, to accomplish the business goals, and ultimately to generate classification of experiences in interactions between entrepreneurs (as individual or collective) and other agents in the population. However, Weber's formulation is limited to a collection of "moral-capitalism" considerations, wherein the modern order he aimed to achieve did not receive proper attention, making the classification of entrepreneur to be unfeasible as the new entrepreneur identity is merely constrained to internal definition (observing similarities and differences), and has yet to be established externally through individual practices that build relations with other agents.

Swedberg (2009: 20-21) found a number of substantial points in the work of Schumpeter, in which capitalism do not indeed attempt to create a new social order (profit and ownership have insignificant impact and even create unemployment), hence the abundance of entrepreneurs would lead the system of capitalism to be in a transitional state. Swedberg provided a collection of "competition-accumulation" considerations, wherein entrepreneurs would always have innovative tendencies by conducting experiments that will have impact on competition 
due to business rivalry of accumulating capital. There is more concept development observed here as a classification of capitalist entrepreneur has been given: capitalists with few innovations (traditional entrepreneurs) in contrast to those with numerous innovations (dynamic entrepreneurs). The lack of this classification is that it is limited to interactions among entrepreneurs (it does not elaborate on entrepreneur identity based on their interaction with agents other than the entrepreneurs themselves within the population).

Upon observation of the entrepreneur behavior model presented by Carol Moore (1989), it is understood that a new entrepreneur will grow by undergoing a social and personal character development process through a triggering event (Bygrave \& Zacharakis, 2010: 50, Hatten, 2011: 29). This triggering event occurs in relation to one's personal experience in their activities (experience in taking risks, dissatisfaction or loss of employment, formal education, age and gender identification, and personal commitment) and collective domains (social networks, groups/ teams, parents, family, and role models) which will concurrently determine the focus of their attention in implementing innovations and strategies for gestation activities. Entrepreneur identity in this model is very much determined by a collection of "triggering event-entrepreneurship implementation" considerations, hence this definition is more developed and has broadened the formulation of entrepreneur identity provided by Swedberg (2009). Entrepreneur identity becomes more distinct as entrepreneurship implementation is found to have three forms: establishing and selling company/business (business founder), maintaining company/ business (manager), and developing company/ business (leadership entrepreneur) (Bygrave \& Zacharakis, 2010: 547).

Entrepreneurship implementation to business founder entails: seeking new ideas; starting a venture; motivated by opportunities; developing and implementing a vision; establishing an organization around the area of opportunity; preceding and inspiring others; creating changes within a competitive environment. Entrepreneurship implementation for manager involves: maintaining business operation; running business; motivated by available resources; planning, organizing, forming staff, and monitoring; increasing organization efficiency; monitoring of personnel; maintaining consistency and predictability.

A business founder will decide whether the business is to be sold for profit or not, and if she were to sell it, the options available would be for her to remain working in that company, to establish a new company, or to seek another employment. A business founder will also consider whether she would continue to lead the business or find someone more experienced to maintain and organize the company which has become more complex and competitive, so that she could focus on other matters of importance such as product or technological innovations. An entrepreneur may also have the option of leading her company to grow exponentially or remain satisfied with the existing market share. This article, however, merely focuses on the measures or actions undertaken by entrepreneurs in maintaining their businesses (ibid: 532-533).

To this point, it may be understood that the identity of entrepreneur is characterized by four dimensions: triggering event, innovation, strategy of gestation activity (stipulated in the business plan), and entrepreneurship implementation. Thereby, entrepreneurs are individuals triggered by their experiences in the collective and individual domain of activities who implement their focus of entrepreneurship by utilizing their business planning and innovative capabilities.

\section{Young Entrepreneurs in Indonesia within the Entrepreneur Identity Framework}

In this section, the four dimensions of entrepreneur identity will be discussed by 
using data obtained from empirical conditions of youths and businesses in Indonesia that are published via YouTube. Categorization of young age is taken from Republic of Indonesia Law number 40 of 2009 about Youth, article 1, chapter 1 that describes youths are Indonesian citizen who enters an important period of growth and development aged 16 (sixteen) to 30 (thirty) years. The young entrepreneurs examined as data sources were: Sandiaga Uno (PT Saratoga Investama Sedaya), Nadiem Kariem (founder of Go-Jek), Kevin Mintaraga (CEO of Bridestory), Budi Susilo Setiawan (founder of MT Farm), and Haidhar Hibatullah Wurjanto (Restaurant Momo Milk Barn).

\section{Sandiaga Uno}

At the age of 28, Sandiaga Uno had founded PT Saratoga InvestamaSedaya, a limited liability company (PT). His triggering events among others were: loss of employment (he was terminated from his job and had difficulties in securing new employment), formal education (has a master degree from George Washington University with a GPA of 4.00), commitment (4 As mindset: kerja keras (work hard), cerdas (work smart), tuntas (work thoroughly), ikhlas (work sincerely); working smart or intelligently means developing knowledge, utilizing technology and innovations; working thoroughly means all activities we undertake should have objectives and we must achieve those objectives; working sincerely means that once we have truly put in our maximum efforts, we should leave the rest in the hands of Allah the Glorified and Exalted, and not forget to always give alms; expand relations with people who are optimistic, positive and successful because goals can be more easily achieved through collaborations; the more optimistic, positive and successful people there are to collaborate with, the higher the prestige and reputation of the Indonesian nation will be), role model (William Soeryadjaya owner of PT Astra Honda Motor), team (collaborates with optimistic individuals: Rosan Perkasa Roeslani and Edwin
Soeryadjaya (Grahadyarini, 2008). The significant innovation he implemented was changing the transactions of his financial consultancy business, in which he was paid in company shares instead of money. This innovation accelerated company growth and altered the core of the business from financial restructuring to company acquisition. There is no data available on the internet regarding his company's business model, although he did state that business plan is necessary for survival, and the company should advance to experience scaling-up and subsequently create new business planning (Ayopreneur.com). Sandiaga Uno's entrepreneurship implementation is from that of an entrepreneur to an entrepreneur leader and he has even left several important positions of companies under the Saratoga Group (Indrastisi, 2015), including the first company that he acquisitioned: PT Adaro Positive Energy Tbk.

\section{Nadiem Makarim}

Nadiem Makarim founded PT Go-Jek Indonesia at the age of 27 . The triggering events were: experiences in taking risks (failed 3 times in start-up businesses without giving up), work experience (he was First Managing Director at Zalora and obtained practical lessons about online business and was positioned as Chief Innovation Officer at Kartuku where he gained experience regarding payments), commitment (problems in Indonesia are seen as opportunities, the goal of business is to provide welfare for others, and developing business to create leaders in Indonesia), team (along with a friend bearing the same vision Alamanda Shantika Santosa who at the time was the Vice President of Technology for Go-Jek), parents (his father is Nono Anwar Makarim who used to be a member of the KPK (Corruption Eradication Commission) ethics committee, and he is always reminded by his parents that he should contribute to Indonesia). He's achieved numerous innovations, among others: designing Go-Jek as an internetbased technological application instead of a 
public transport company, designing spinoff applications for delivery services-Go-Ride, Go-Car, Go-Food, Go-Mart, Go-Send, GoBox, Go-Pulsa, Go-Massage, and others - that are in high demand by urban communities (this impacted on lowering selling prices and keeping consumer's cost at a minimum in obtaining various provisions of services), changing conventional organization culture in terms of working hours and decision making (there is no strict regulation on working hours and leaves, and junior managers are even authorized to make decisions). Go-Jek's model/ business plan: as a customer based technology start-up, its business traction (business progress and momentum for growth) is determined by the number of users and transactions, and in order to maintain this figure, Go-Jek has 5 work principles to ensure the company keeps innovating: be fearless (courage), customer obsession, zero ego, number/data driven, and inspire others. The current entrepreneurship implementation of Nadiem Makarim is to continue being the CEO of Go-Jek due to his commitment of constantly creating young Indonesian leaders impervious to failures.

\section{Kevin Mintaraga}

Kevin is known as the founder of the internet marketing agency called Magnivate at the young age of 24 , and he is now the CEO of Bridestory. The triggering events for him becoming an entrepreneurs among others were: parents (his life spent playing video games while pursuing studies in Australia had to end due to his parents illness and he was forced to work hard since), work experience (his experience as an account executive at a graphic design studio had led him to meet many people and broadened his relations), commitment (he is committed to internet based business as it is a constantly developing venture, he listens to numerous experiences from people intending to open business opportunities, he has a high level of integrity in order to maintain trust of clients and users), team (he runs the business while some of his friends manage the projects, design the website, and are experts in internet technology), age identification (being at a young age and unmarried provides him with no sense of fear in failing since he is yet to bear any significant responsibility). The innovations launched by Kevin and his team continuously follow technological advancements which provide added value to consumers and reduce costs, and to develop this they have recruited talented individuals highly determined to apply their outstanding capabilities. As the CEO of Bridestory, he conducted a market research and found that the annual expenditure spent by Indonesians for weddings almost reached US $\$ 4$ million. He uses the Lead Generation business model to develop a website in the form of a marketplace for items relating to wedding and its preparations. He gathered various service providers and collaborated with them through his website, wherein his profit is secured when vendors begin to subscribe with payment. He explained that Bridestory is a start-up with a business appeal in higher profitability, which sees the potential of growth and scaling-up, because the wedding business relates to honeymoon businesses and housing/property businesses. Kevin's entrepreneurship implementation is that he prefers to be a business founder, so that once the company has developed he prefers to sell them to a company better experienced at managing big companies, which was his exact decision for his former company, Magnivate, that he had sold to WPP London.

\section{Budi Susilo Setiawan}

Budi Susilo Setiawan is the founder of Mitra Tani Farm (MT Farm) in 2004 at the age of 22. His triggering events, among others, are: formal education (a graduate of the Department of Animal Husbandry, IPB (Bogor Institute of Agriculture), in which his venture was initiated mid-studies in 2002, and it was continued after 
graduating), team (he worked along with his college friends Bahrudin, M. Afnan, Amrul L, Budi SS, Sucahyo, Faisal), and commitment (Islam, his religion, advised its followers to be productive and engage in business ventures, and Indonesia's agrarian characteristics may lead Indonesians to follow the examples of religious messengers and prophets who had managed livestock, this may have encouraged him to be productive in managing livestock/ animal husbandry). His innovations are quite simple, that is through motivational donations of providing assistance to breeders in Ciampea, Bogor who were in need of materials, not only by directly providing the needed materials, but also by encouraging them to engage in efforts of goat and sheep fattening in order to produce profit enabling them to procure those materials monthly. His business model and plan is the core-plasma scheme, wherein MT Farm serves as the core providing market regulation, market channels, and supporting systemssuch as standard operating procedures-for breeders who carry them out. Such core-plasma business model is able to assist in fulfilling the markets excessively high demand for goats and sheep (for daily consumption and the religious sacrifice of livestock called aqiqah and qurban), and it also helps create efficiency in systems relating to monitoring, investment, and land area needed for producing large livestock supplies. Budi Susilo Setiawan's entrepreneurship implementation is that he continues to be involved in scaling-up this business venture as there remains a huge gap between demand and supply of goats and sheep. Hence, MT Farm initiated in developing the sale of livestock plots to investors interested in pursuing this business sector.

\section{Haidhar Hibatullah Wurjanto}

At the age of 25 in 2010, Haidhar Wurjanto established his venture, that he had done so multiple times since high school, in the form of a restaurant called Momo Milk Barn with a current number of 60 employees. His triggering events, among others, are: role model (Haidhar considers his friend's father as the person he looks up to during high school, his role model was at the time an entrepreneur living in an elite housing compound in Bogor who owned a luxurious residence and was often seen at home spending ample quality time with his family. This was a stark contrast to his life, wherein his father, who has a doctoral degree, found it difficult to provide quality time with the family and their house was not as grand as his friend's. He subsequently learned and realized that becoming an entrepreneur provides more financial freedom and unrestricted time), experiences in taking risks (encouraged by his role model, he started his first business at the age of 17 by venturing to cater Japanese cuisine, he has as of current failed 8 times in his business ventures), commitment (since his initial business venture, he enjoyed being an entrepreneur and had found his great calling, he is committed not to work as an employee and to create a business which can provide employment for many people instead, he also chose the hospitality sector because enjoys making customers happy), formal education (as a graduate from the Department of Management, IPB, he continues to seek knowledge by reading books and he never stops finding innovations), and group (he constantly encourages the spirit of entrepreneurship through his relations in the business community). Innovation is his most substantial factor as the location of his business is in the city of Bogor which has a highly competitive environment for the restaurant business. He must, therefore, continuously seek popular concepts of service provisions as well as food and beverage products, as an example, he had created KitKat Matcha Tea which was a top sales product for two months. Haidhar employs the canvas business model with obvious strengths in customer segmentation and value proposition (Ghaffari, 
2014). His entrepreneurship implementation is that he continues to manage his company and minimize existing business obstacles such as incomplete business permit, recruitment of quality employee, and also preparing the development of dairy cattle and milk processing businesses.

\section{Base of Action Identity of Young Entrepreneurs}

The five young entrepreneurs described above have four dimensions of entrepreneur identity in their journey of establishing to developing their respective business. The description not only explained who these young entrepreneurs are, but also what they have done to clearly portray who they are. The actions they have conducted can be simplified into three identities: 1) young entrepreneurs are individuals who are aware of the various life events they experienced personally and collectively, and utilize them as a source to develop their self-potential as an entrepreneur and to initiate a commitment of accomplishing their dreams; 2) young entrepreneurs are individuals who are aware that their commitment of accomplishing their dreams relates to change towards better social welfare, hence they continuously innovate and create business models and plans when they establish, maintain, and develop their businesses; 3) young entrepreneurs are individuals who are aware that their businesses must have the potential to grow and develop, and this consequently leads to them always maintaining the trust of their users, clients, and investors, as well as constantly increasing their business appeal. The three specifications above are the identities that young entrepreneurs in Indonesia base their actions on.

An interesting issue is observed in this discussion, namely the emphasis given by young entrepreneurs concerning their intent of changing the human condition to becoming more prosperous. This raises a significant question in sociology, how are entrepreneurs while competing against each other able to create a better condition of prosperity and welfare? Particularly, since competition is aimed at achieving market domination for the sake of accumulating profit and other capital, leading to entrepreneurs being constantly illustrated as a very individualistic and egotistic group. Nevertheless, this assumption does not deny the possibility that nearly all the young entrepreneurs above has an ideal condition of human welfare they intend to achieve (perhaps the most irrelevant in this matter are Kevin and Haidhar). Sandiaga wants this nation to be full of people who can easily collaborate in accomplishing good objectives, Nadiem wants this nation to bear leadership capacity, and Budi wants people to always participate in managing agriculture and livestock potentialities available in rural areas as Indonesia is an agrarian nation. In this aspect, the three identities serving as the basis for their actions may be seen as the entrepreneurs' social movement aimed at improving social welfare. Therefore, it is necessary to find the synthesis of young entrepreneur social movement through a different means.

\section{Social Movement Identity of Young Entrepreneurs}

The construct of conceptual framework on the identities young entrepreneurs base their actions on may even lead to various syntheses of action with differing phases and situations. The three identities mentioned in the previous section are interconnected. Identity 1 and 2 relate to the situation of initial social capital and network utilization in establishing a business organization with an agreed vision of change and is clear in the founders' division of tasks, this may be regarded as the initiation phase. Identity 2 and 3 relate to the situation of utilizing business organization to seek new social capital and networks for developing business intensity and organizational extension in order to confront bigger challenges and competition, 
as there may still be people who are resistant and dislike business expansion which changes the strategic standing of other business groups, this may be considered as the strategic phase. Identity 1 and 3 relate to the use of both new and initial social capital and networks so that trust in the business organization afforded by existing social networks becomes stronger, and organizational performance in achieving the dream of improving human welfare can be easily undertaken with proper control over various prevailing obstacles, this phase may be regarded as the control phase.

Bjerke (2010: 104) has presented a concept regarding the type of entrepreneurship situation found in the Indonesian community, namely the business situations (in markets), common situations (in institutions), and social situations (in public places). Business situations or market-based entrepreneurship contains initial actions of entrepreneurs relating to knowledge on social capital and networks (Bjerke, 2010; Lippman, Davis \& Aldrich, 2005 in Wiroto, 2016: 203). Network and networking are substantial instruments of entrepreneurship with significant roles in the establishment, development, and growth of small enterprises (Shaw \& Conway, 2000 in Bjerke, 2010). The initiation phase occurs in business situations wherein a new entrepreneur optimizes all her network and networking potential to carry out a number of innovations aimed at surviving market competition and business situations.

What is referred to as common situations are a more collective form of entrepreneurship focused on more extensive actions and outcomes as a response to changes exemplifying the global age. The strategic phase is included in this situation, wherein entrepreneurs prepare the foundation for building a strong, socially inclusive economy within the globally interconnected world (De Bruin, 2003 in Bjerke, 2010: 107). The strategic phase occurs due to the formation of an entrepreneur collective based on their desire to help improve entrepreneurship growth in their area of operation through several means, such as by identifying problems which can be turned into opportunities for gaining profit and creating business organization through private public partnership and innovations that will be used to change opportunities into businesses. Additionally, the strategic phase results in an entrepreneurship community as the activities of both the public and private sectors have raised and promoted their region to be more globally connected to other regions which also enhance their economic activities worldwide (Bjerke, 2010: 114-116).

There is a difference in the definition of social situations and common situations. Common situations are those in which public entrepreneurship seeks what has been lost in the local community, namely the quality of social interaction or sociality that has begun to wane due to the marginalization of its roles. Meanwhile, social situations are those in which entrepreneurship activities occur due to people being aware of existing opportunities to fulfill needs that remain unmet that the welfare system may or will never fulfill, and social situations collectively gather necessary resources (generally are the volunteers, money, and land and property) then utilize them to make changes (Thomson, 2000: 238 in Bjerke, 2010: 111). Bjerke, however, gave the impression of putting social entrepreneurship after public entrepreneurship, as he is of the opinion that social entrepreneurship is difficult and can only be undertaken by individuals having extraordinary capabilities. If we observe the definition of the third phase or the control phase, then there are increasingly more entrepreneurs involved in the strategic phase or public/commons entrepreneurship, which will subsequently lead to a strong probability in the emergence of an entrepreneur collective for sharing problems, finding solutions, and providing mutual assistance to fulfill their respective expectation concerning social 
changes for better welfare and prosperity. Thus, they will have the capacity to control situations which may lead to the decrease of public entrepreneurship quality as well as control situations which may open and pave the way to resolve prevailing social issues, such as poverty.

In this section, it is concluded that there are three identities relating to young entrepreneurs' social movement, namely: initiation phase, strategic phase, and control phase. Out of the five young entrepreneurs discussed above, it may be understood that the identity of their movement had only reached the initiation phase, wherein Sandiaga, Nadiem, and Budi had only made initial commitment for stepping into the strategic phase, and no concept is yet to be observed regarding their intent of reaching the control phase.

The social movement identity of these young entrepreneurs provides a substantial contribution to the concept of social movement in general. Mario Diani in The Wiley-Blackwell Encyclopedia of Social and Political Movements (Snow et al., 2013) notes that Charles Tilly, in 1978, had provided an explanation that collective action can no longer be achieved by merely being dependent upon particular social character of a population pertaining to prevailing inequality and discrimination at the macro structure level. Collective action is restricted because it does not take into consideration existing social relations and social representations found in the various social categories (class, trade, gender, nationality, religion, and others), and thus, social category and social networks (category and networks or catnet) become an important causal factor of collective action. Diani subsequently posed a significant question, why is social character in certain categories more apparent than others, is this caused by the dependence on entrepreneurial dissimilarities (on fields of social category) in terms of adequate resources, or unequal opportunity provided by the government institutional management system in encouraging collaboration among organizations? Mario Diani's elaboration is very clear that young entrepreneurs' social movement identity will arrive at the strategic phase because the government does not truly desire to manage entrepreneurial resources and create collective action of entrepreneurs which provides benefits to the public, although it is obvious that the government greatly requires positive growth in the entrepreneurship sector.

Regarding the social movement identity of young entrepreneurs at the control phase, a contextual explanation from the concept of social movement entrepreneur has been provided by John McCharty and Mayer Zald in 1977 (Suzzane Staggenborg in Snow et al., 2013). Staggenborg notes that McCharty and Zald explained that the modern social movement has become more professional, as characterized by full-time leadership, a large amount of recorded membership, and reliance on constituents who are conscious and do not intend to gain direct benefit from the success of accomplishing its goals. This movement becomes organized by issue entrepreneurs and furthermore, Gerhards and Rucht (1992) explain that movement entrepreneurs would frame the issue in a way that would attract followers and, they must link the attention of the diverse participants present to form a coalition which extends to various organizations and movements (Staggenborg in Snow et al., 2013). This signifies that the problems entrepreneurs encounter at the strategic phase will drive them to be involved in a bigger issue in order to create social changes and actualize social welfare, so that a coalition among them will be established and will subsequently provide proper conditions for entrepreneurship growth.

\section{Conclusion}

The attempt of finding a conceptual framework in forming the identity of young entrepreneurs in Indonesia resulted in the 
answer that young entrepreneurs have four dimensions of status identity, three identities serving as basis of action, and three identities of movement. Consequently, we would like to invite all social scholars, particularly those in the sociology discipline, to utilize and improve this framework whilst conducting their research on entrepreneurship in Indonesia.

Some sociological studies which need to be carried out and may utilize the conceptual framework of young entrepreneur identity, in our opinion, among others, are: how do young entrepreneurs select their team/group in establishing a business, distributing work and managing task coordination in their business organizations? What is the influence of social networks on the development and growth of business organizations? What are the experiences of young entrepreneurs in implementing self commitment when they initially established their business organization, and when the business started to grow and develop? What is the influence of innovations to the continuity of young entrepreneurs' businesses? How do young entrepreneurs adapt to situations that may be disadvantageous to the company? How do young entrepreneurs keep their focus and remain calm not to hastily undertake business growth and expansion? What factors can instill in young entrepreneurs the confidence of engaging in collaboration with the public sector? How does the government perceive the potential of young entrepreneur's involvement in the development of their respective region? How does the government actively participate in resolving several issues concerning young entrepreneurs' activities rejected by the community? How does the government urge young entrepreneurs to develop a positive attitude of entrepreneurship in their institution and the whole community?

There are, undoubtedly, many more research questions to fill the list in the previous passage, the issues above, however, cover basic problems that are as of current insufficiently researched. We are certain that more sociological research on entrepreneurship will encourage more optimism and scientific entrepreneurial attitude in the community, particularly for college students deciding to become young entrepreneurs or young employees.

\section{Acknowledgement}

This paper is based upon work supported by HSBC Indonesia Research Award 2017 (HIRA 2017). Any opinions, findings, and conclusions or recommendations expressed in this paper are those of the author(s) and do not necessarily reflect the views of PT Bank HSBC Indonesia.

\section{References}

Aidin, S. (2015). New Venture Creation: Controversial Perspectives and Theories. Economic Analysis, 48(3-4), 101-109.

Ayopreneur. (2014). Sandiaga Uno tentang Cara Beralih dari Fase Survival ke Scaling Up. Retreived from http://www.ayopreneur. com/sandiaga-s-uno/sandiaga-unotentang-cara-beralih-dari-fase-survivalke-scaling-up.

Bygrave, W. \& Zacharakis, A. (2010). Entrepreneurship. USA: Wiley.

Bjerke, B. (2010). Entrepreneurship, Space and Place. In F. Bill, B. Bjerke, \& A. W. Johansson (Eds.), (De) Mobilizing Entrepreneurship Discourse: Exploring Entrepreneurial Thinking and Action. Cheltenham: Edward Elgar.

Bygrave, W. \& Zacharakis, A. (2010). Entrepreneurship. USA: Wiley.

DailySocial TV. (2015). DScussion \#13: Interview with CEO, Co-Founder Bridestory Kevin Mintaraga [Video]. Retrieved from https:// www.youtube. com/watch? $v=$ nUum1DxqSo.

DailySocial TV. (2015). DScussion \#14: Interview with CEO, Co-Founder Bridestory Kevin Mintaraga (Part II). [Video]. Retrieved from https://www.youtube.com/ watch?v=LWlm6wiXdUQ. 
DailySocial TV. (2015). DScussion \#15: Interview with CEO, Co-Founder Bridestory Kevin Mintaraga (Part III). [Video]. Retrieved from https://www.youtube.com/ watch?v=KpiuNXka-9M.

Diani, M. (2013). Catnets. In D. A. Snow, D. t. Porta, B. Klandermans, \& D. McAdam. The Wiley-Blackwell Encyclopedia of Social and Political Movements. Malden, MA: Wiley. doi: 10.1002/9780470674871.wbespm021

Ghaffari, M. A. (2014). Pengembangan Model Bisnis Momo Milk (Studi Kasus Kafe Momo Milk Bogor) (Tesis Master). Bogor: Institut Pertanian Bogor.

Ghosh, P. (2014). Max Weber and The Protestant Ethic: Twin Histories. Oxford: Oxford University Press.

Grahadyarini, L. (2008, September 4). Kebangkitan Hidup Sandiaga Uno. Kompas. Retrieved from http://megapolitan.kompas. com/read/2008/09/04/0124478/Kebangkitan. Hidup.Sandiaga.Uno

Hatten, T. S. (2012). Small Business Management: Entrepreneurship and Beyond. USA: Southwestern, Cengage Learning.

Hodkinson, P. (2007). Youth Cultures: A Critical Outlines of Key Debates. In P. Hodkinson \& W. Deicke (Eds.), Youth Cultures: Scenes, Subcultures, and Tribes. New York: Routledge.

Holm, H. J., Nee, V., \& Opper, S. (2011). Entrepreneurs Under Uncertainty: An Economic Field Experiment (CSES Working Paper No. 60). Retrieved from http:// www.economyandsociety.org/wp-content/ uploads/2013/08/wp60_HolmNeeOpper_ Uncertainty.pdf

Hubungan Alumni IPB. (2013). Budi Susilo S. Pengusaha Sukses MT Farm. Retrieved from http://hubunganalumni.ipb.ac.id/ budi-susilo-setiawan-pengusaha-suksesmt-farm/

Indo Mixed. (2016). Nadiem Makarim CEO GO-JEK I Satu Indonesia. [Video]. Retrieved from https://www.youtube.com/ watch?v=IcYjoxV6mvg.
Indrastisi, N. (2015, July 4). Sandiaga Uno Lepaskan 16 jabatan di Saratoga. Kompas. Retrieved from http://bisniskeuangan. kompas.com/read/2015/06/04/094317026/ Sandiaga.Uno.Lepaskan.16.jabatan . di.Saratoga

IPB Official. (2016). Haidhar Hibatullah Wurjanto. [Video]. Retrieved from https://www. youtube.com/watch? $\mathrm{v}=\mathrm{HBClsTBEliI}$.

Jenkins, R. (2008). Social Identity (Third Edition). London: Routledge.

Kautonen, T., van Gelderen, M., \& Fink, M. (2015). Robustness of Theory of Planned Behavior in Predicting Entrepreneurial Intentions and Actions. Entrepreneurship Theory and Practice, 39(3), 655-674. doi: 10.1111/etap.12056

Knudsen, T., \& Swedberg, R. (2009). Capitalist entrepreneurship: Making profit through the unmaking of economic orders. Capitalism and Society, 4(2). doi:10.2202/1932-0213.1057 Macionis, J. J. (2008). Sociology. New Jersey: Pearson Prentice Hall.

McKenzie, B. (2009). Investigation of the Dynamic of Entrepreneurial Change. International Review of Business Research Papers, 5(5), 365-372. Retrieved from https:// www.bizresearchpapers.com/29.Brian.pdf Minza, W. M. (2014). Masa Muda Sebagai Masa Transisi. In M. N. Azca, D. S. Widhyarto \& O. R. Sutopo (Eds.), Buku Panduan Studi Kependudukan: Teori, Metodologi dan Isu-isu Kontemporer (pp. 11-26). Yogyakarta: YouSure. Nassif, V. M., Ghobril, A. N., \& da Silva, N. S. (2010). Understanding the entrepreneurial process: a dynamic approach. BAR-Brazilian Administration Review, 7(2), 213-226. doi:10.1590/s1807-76922010000200007

Neumann, W. L. (2014). Social Research Methods: Qualitative and Quantitative Approaches. Essex: Pearson Education Limited.

PKPU Human Initiative. (2014). Pintu Inspirasi Episode 4 "Kisah Sukses Pengusaha Muda. [Video]. Retrieved from https://www. youtube.com/watch?v=jK_Qczmf-gU. 
Rappler Indonesia. (2015). Sesi Inovasi TeknologiPertumbuhan Ekonomi, Nadiem Makarim CEO Go-Jek. [Video]. Retrieved from https://www. youtube.com/watch?v=UNXXLKP9dkg.

Ratomo, U. T.(Ed.). (2014, June 19). Semarak Young Business Movement 2014. Antaranews. Retrieved from http://www. antaranews.com/berita/439979/semarakyoung-business-movement-2014.

Ruef, M. (2010). The Entrepreneurial Group: Social Identities, Relations, and Collective Action. Princeton and Oxford: Princeton University Press.

Rumah Jenggala. (2014). Membentuk Karakter Juara oleh Sandiaga S. Uno. [Video]. Retrieved from https://www.youtube.com/ watch? $\mathrm{v}=\mathrm{JX} 3 \mathrm{si} 4 \mathrm{H} 3 \mathrm{sNg}$.

Saade, F. (2013). Towards Understanding Nascent Entrepreneurship: A Theory of Planned Behavior Perspective (Master's Thesis). Retrieved from http://epub.lib.aalto.fi/en/ethesis/ pdf/13312/hse_ethesis_13312.pdf

Saefullah, A. (2016). Bincang Bisinis Nadiem Makarim CEO GOJEKStartup Unicorn Pertama di Indonesia. [Video]. Retrieved from https:// www.youtube.com/watch?v=pbStiaJUXZk.

Samuelsson, M., \& Davidsson, P. (2008). Does venture opportunity variation matter? Investigating systematic process differences between innovative and imitative new ventures. Small Business Economics, 33(2), 229-255. doi:10.1007/s11187-007-9093-7

Staggenborg, S. (2015). Entrepreneurs, movement. In Snow, D., della Porta, D., Klandermans, B., \& McAdam, D. The Wiley-
Blackwell Encyclopedia of Social and Political Movements. doi: 10.1002/9781405198431. wbespm083.

Sutopo, O. R. (2014). Perspektif Generasi dalam Kajian Kepemudaan. In M. N. Azca, D. S. Widhyarto \& O. R. Sutopo (Eds.), Buku Panduan Studi Kependudukan: Teori, Metodologi dan Isu-isu Kontemporer (pp. 1126). Yogyakarta: Yousure.

The Crafters. (2017). The Crafters 01 // Kevin Mintaraga. [Video]. Retrieved from https://www.youtube.com/ watch? $\mathrm{v}=\mathrm{LKK} 6 \mathrm{HISHVng}$.

Vanguard Ace. (2011). Peluang Usaha Bagi Wirausahawan Muda Sukses Indonesia. [Video]. Retrieved from https://www. youtube.com/watch?v=pzEZK2bvjCs.

Vanguard Ace. (2011). Sandiaga Salahuddin Uno Entrepreneurship Character Building. [Video]. Retrieved from https://www.youtube.com/ watch?v=NnEK6nJy3Zw

Viinikainen, J., Heineck, G., Böckerman, P., Hintsanen, M., Raitakari, O., \& Pehkonen, J. (2016). Born Entrepreneur? Adolescents' Personality Characteristics and Self-Employment in Adulthood (IZA Discussion Paper No. 9805). Retrieved from http://ftp.iza.org/dp9805.pdf Wiroto, D. W. (2016). Kapital sosial dan kepemimpinan dalam pengembangan kompetensi usaha mikro dan kecil di era MEA: Sebuah tinjauan konseptual ringkas. In M. Ilyas, R. Junaid, H. Asri (Eds.), Seminar Nasional 2016: Kesiapan Daerah Menghadapi Masyarakat Ekonomi ASEAN (MEA) (pp. 591601). Sulawesi Selatan: UNCP Press. 